\title{
Determinants of University Working-Students' Financial Literacy at the University of Cape Coast, Ghana
}

\author{
Abraham Ansong $^{1} \&$ Michael Asiedu Gyensare ${ }^{2}$ \\ ${ }^{1}$ School of Business, University of Cape Coast, Cape Coast, Ghana \\ ${ }^{2}$ Department of Organisation \& Human Resource Management, University of Ghana Business School, Accra, \\ Ghana \\ Correspondence: Abraham Ansong, School of Business, University of Cape Coast, Cape Coast, Ghana. Tel: \\ 233-242-829-965. E-mail: ansongabraham@yahoo.com
}

Received: January 30, 2012

Accepted: March 5, 2012

Published: May 1, 2012

doi:10.5539/ijbm.v7n9p126

URL: http://dx.doi.org/10.5539/ijbm.v7n9p126

\begin{abstract}
This paper explores the determinants of university working-students' financial literacy. It further seeks to establish the relationship between financial literacy and certain demographic characteristics. This study adopted a correlational research design as the framework to examine the relationship between variables without determining cause and effect. Data were randomly collected from 250 undergraduate and postgraduate students of a public university in Ghana. The paper found that age and work experience were positively related to financial literacy. Also, mother's education was positively correlated with respondents' financial literacy. However, level of study, work location, father's education, access to media and the source of education on money were all not significantly correlated with financial literacy. A key recommendation is that given the positive correlation between mother's education and financial literacy, parents should be actively involved in designing educational programs on financial issues at the basic and high school levels for their kids. It is believed that such a step forward will help parents to guard and guide their children's financial behaviours.
\end{abstract}

Keywords: financial literacy, determinants, university-working students, Ghana

\section{Introduction}

University students have many challenges to overcome in order to attain their optimal academic performance. It takes a lot more than just studying to successfully complete an academic programme. A number of issues such as time management, financial problems, sleep deprivation, social activities, and for some students taking care of their families, can all pose their threat to a student's academic performance. In Ghana, like most developing countries, funding is deemed to be a great challenge in acquiring a tertiary education. The Students' Loan Scheme was therefore established in January 1988 under PNDC Law 276. The Students' Loan Scheme is a financial arrangement under which Ghanaian Students enrolled and pursuing approved courses in tertiary institutions in Ghana are granted loans to assist with the financing of their education.

While both government and parents are doing their very best to provide financial assistance for students in Ghana, what has been left to chance is an examination of the financial literacy among the beneficiary of these supports. The need for such a study is more pronounced where the subjects are university working-students. The financial hurdle such category of students have to deal with goes beyond raising funds to pay school fees and living expenses but for some, this include catering for other dependents out of their meagre salaries and other sources of funding According to Norman (2010) financial education refers to knowledge or an understanding on the importance of money and the use of money, it answers the question, why spend on this as opposed to that. It can literally be summed up as the wise use of money. Financial literacy is the ability to understand finance. More specifically, it refers to the set of skills and knowledge that allow an individual to make informed and effective decisions through their understanding of finances.

Empirical studies have established the influence of financial literacy on financial behaviour. People with low financial literacy are more likely to have problems with debt (Lusardi \& Tufano, 2009).This implies that without proper financial literacy, Ghanaian working-students in view of their financial challenges could run into debts. van Rooij, Lusardi and Alessie (2007) showed that individuals who have low financial literacy are significantly 
less likely to participate in the stock market. Similarly, van Rooij et al. (2008) provided evidence of an independent and positive effect of financial literacy on wealth accumulation over and above the effect of other determinants such as income, age, education, risk tolerance, patience, and basic cognitive ability.

Financial literacy is an important component of sound financial decision-making, and many young people wish they had more financial knowledge (Lusardi, Mitchell \& Curto, 2010). There is the need to improve financial literacy of individuals, especially students at university level so they can have positive cash management attitudes before they enter the job market. This positive attitude will help them to practice proper personal financial management as working adults (Dahlia, Rabitah \& Zuraidah, 2009).

Ansong (2011) investigated the level of knowledge among university freshmen business students within the University of Cape Coast, Ghana. There were 343 business-major first-year students enrolled in the school of business that were tested on 20 multiple choice questions dealing with basic knowledge of financial issues which should be understood in order to function in everyday life. The highest test score was $75 \%$, achieved by only one student and the lowest was $5 \%$, achieved by 7 students. The average score was $35.87 \%$ for all students. In the context of such widespread financial illiteracy and increasing need for better financial understanding, it has become imperative to assess not only the current level of financial literacy among the student population but also to investigate its determinants, as it might help to formulate policy interventions. Understanding financial literacy among young people is of critical importance for policymakers in several areas; it can aid those who wish to devise effective financial education programs targeted at young people as well as those writing legislation to protect younger consumers (Lusardi et al., 2010). Our study appears to be the very first in Ghana to contribute to literature on the predictors of financial literacy among university students.

\section{Review of Related Literature}

There has been a rising interest in the financial literacy from academic community, international organizations and governments recently (Olga, 2011). Most of the recent studies have concentrated on the financial planning of university students because empirical evidences have demonstrated that most of them fail to plan their expenditure and unexpectedly experience financial problems. University students report having high debt, serious credit card usage, and high stress, as well as low financial satisfaction due to the lack of financial management skills (Nellie, 2002; Norvilitis et al., 2003; Norvilitis et al., 2006). Young adults may be unprepared to effectively manage the psychological costs associated with financial problems such as increased levels of stress and decreased levels of well-being (Norvilitis \& Santa, 2002; Roberts \& Jones, 2001). However, it is generally accepted among researchers that, financial education is the key to decrease financial problems, especially among young adults. Learning theories form the basis for our study.

In psychology and education, learning is commonly defined as a process that brings together cognitive, emotional, and environmental influences and experiences for acquiring, enhancing, or making changes in one's knowledge, skills, values, and world views (Illeris, 2004; Ormrod, 1995). The level of knowledge in any subject, including financial knowledge, can therefore be connected to variables, such as: Age, gender, level and programme of study, parents' level of education, accessibility to media, sources of education on money matters, place of residence, among others.

There is considerable evidence that people who studied economics or business courses are more likely to be financially knowledgeable. This argument was supported by research of Lusardi and Mitchell (2007b) and Chen and Volpe (2002). The findings of Chen and Volpe (1998) indicate that, in terms of participants work experience and ages, participants with more years of work experience are more knowledgeable than those with less experience. Participants in the age category of 20 to 29 and 40 or older exhibited greater knowledge than the other age group. According to Agarwal et al. 2009, an increase in age also comes with the accumulation of knowledge based on practical life experiences. The initial rise with age might be interpreted as an increase in experience, while the subsequent decline could be the result of deteriorating cognitive functions.

Gender has been identified by several empirical studies to have a relationship with the level of knowledge on financial differences. Bernheim (1998) found that males perform better on both financial and macroeconomic questions. Being male is associated with greater financial knowledge also in Italy (Guiso \& Jappelli, 2008). Goldsmith and Goldsmith (1997) suggest that women score worse than men because in general they are less interested in the topics of investment and personal finance and, consequently, use financial services more seldom. Chen and Volpe (2002), and Goldsmith, Goldsmith (1997) linked risk taking and confidence as contributors to gender differences in financial literacy. Similarly, Chen and Volpe (2002), Bajtesmit and Bernasek (1996), and Powell and Ansic (1997) reported that women were more risk averse than men. Conversely, Schubert, Brown, Gysler, and Brachinger (1999) stated that under controlled economic conditions, female subjects do not 
generally make less risky financial choices than male subjects, suggesting that risk attitudes about female investors and managers may be more prejudice than fact. From a gender perspective, male and female differences in financial issues such as attitude, knowledge and overall behaviour is due to different financial socialization during childhood (Lim, Teo, and Loo, 2003). For instance, in most cultures, boys have grown up with the expectation of being the family breadwinner while girls have grown up with the expectation of being the caregiver (Wilhelm, Varcoe \& Fridrich, 1993). Therefore, diversity in gender role expectations would provide different strategies to the financial socialization of boys and girls, and, consequently, the different levels of financial knowledge among them (Falahati \& Paim, 2011).

Environmental issues such as accessibility to media, the educational level of students' parents, and sources of education on financial issues can have an influence on ones learning ability and consequently the amount of knowledge a person acquires. Mandell (2008) has shown that children of college graduates perform better on numerical test. Two papers investigate whether area of residence impacts the level of financial literacy. Similar, Dahlia et al. (2009) established differences in financial knowledge based on mother's education level. Students who reported they learned some or a lot about managing their money from their mothers had higher financial knowledge than students who reported learning about managing their money from their father's. Cole, Sampson and Zia (2008) found that people who live in rural area demonstrate the lowest level of financial knowledge. Guiso and Jappelli (2003) argued that the stock market awareness is correlated with the intensity of social communication in the area of investors' residence. Peress (2004) modelled theoretically the investment of individuals in financial information. He argued that investment in financial education allowed investors to improve portfolio allocation and receive higher risk-adjusted returns. Therefore, we conclude that access to the media and other viable sources of financial information can influence ones level of financial literacy.

\section{Hypotheses}

Based on the literature reviewed, the following hypotheses are formulated to guide the study.

H1: There is no significant relationship between working-students' financial literacy and age, work experience, parents' education, work location, access to media and source of education on money.

H2: There is no significant difference in financial literacy based on respondents' gender, level of study, type of programme and location of workplace.

H3: There is no significant difference in working-students' financial literacy across their demographic characteristics.

\section{Method}

\subsection{Research Design, Participants, Sample and Procedure}

This study adopted a correlational research design as the framework because it is appropriate when attempting to examine the relationship between variables without determining cause and effect (Bluman, 2001). This type of design (Bluman, 2001) can be used to determine the magnitude and direction of the relationship between two or more quantifiable variables. Finally, the correlational research design is not subject to the same types of threats to internal and external validity that can affect experimental research.

Respondents were randomly selected from the University of Cape Coast sandwich programme in the 2010/2011 academic year. The sample used in this study consisted of 250 undergraduate and postgraduate working-students'. Questionnaire as an instrument was used for the data collection. Questionnaires with an introductory letter assuring participants their confidentiality were randomly administered to 250 working-students' in the University of Cape Coast. All questionnaires were completed and returned by respondents for the analysis.

\subsection{Measure}

Apart from respondents' demographic characteristics, 20 multiple choice items constituted the questionnaire for data collection. All items were self-developed and self-administered by the researchers. Descriptive statistics, including mean and standard deviation together with Pearson's product moment correlation were used to establish the relationships between demographic characteristics and working-students' financial literacy. Independent samples t-test was used to examine the differences in financial literacy based on respondents' gender, level of study, type of programme and location of workplace. Again, one-way analysis of variance (ANOVA) was used to analyze the variations in working-students' financial literacy across their age category, father's and mother's education, access to media and source of education on money. Analysis of data in this study was done using SPSS Statistics, version 19.0 at the 0.05 level of significance. 


\section{Results and Discussion}

The means, standard deviations and intercorrelations for the determinants of financial literacy used in this study are detailed in Table 1. In terms of the demographic characteristics, age $(\mathrm{r}=0.215, \mathrm{p}<0.01)$ and work experience $(\mathrm{r}=0.144, \mathrm{p}<0.05)$ were positively related to the financial literacy of respondents. Thus, as one matures "numerically" his/her knowledge on financial issues also increases. In the same vein, it can be argued that "other things being equal", the more acquainted an employee is to a particular job, the more experienced he/she would be and hence the likelihood that he/she will be acquainted with financial issues like wages and salaries, fringe benefits, and savings and investment. On the basis of this logic, it is hypothesize that increases in age and work experience go with knowledge accumulation based on practical life experiences and thus, both were expected to have a positive relationship with respondents' financial literacy level. This finding is in concord with that of Chen and Volpe (1998) and Agarwal et al. (2009). According to Agarwal et al. (2009), the initial rise of participants' financial literacy with age might be interpreted as an increase in experience, while the subsequent decline could be the result of deteriorating cognitive functions. Our sample covered working-students most of whom fall within the age category that may be described as 'the rising in age' ( $84 \%$ of the respondents were within the ages of 20-43 years). Hence, it is worth mentioning that age and work experience are both positive predictors of university working-students' financial literacy. Also, mother's education $(r=0.160, p<0.05)$ is positively correlated with respondents financial literacy. Arguing from sociological literature, it is imperative to say that an "educogenic" family (a family with both parents educated) will invariably motivate their children to move in the same direction as they the parents. Therefore, other things being equal, the higher the educational level of a mother, the more knowledgeable the child is likely to be in financial issues. Hence, mother's education is seen as a positive predictor of respondents' financial literacy. This confirms findings of previous work among college students (Lusardi et al., 2010). However, level of study ( $\mathrm{r}=-0.021, \mathrm{p}>0.05)$, work location $(\mathrm{r}=-0.101$, $\mathrm{p}>0.05)$, father's education ( $r=-0.033, \mathrm{p}>0.05)$, access to media $(\mathrm{r}=-0.043, \mathrm{p}>0.05)$ and the source of education on money $(r=-0.038, p>0.05)$ were all not significantly correlated with respondents' financial literacy.

Table 1. Means, standard deviations and correlations among demographic characteristics and financial literacy

\begin{tabular}{|c|c|c|c|c|c|c|c|c|c|c|c|c|c|}
\hline & Mean & SD & 1 & 2 & 3 & 4 & 5 & 6 & 7 & 8 & 9 & 10 & 11 \\
\hline 1. Gender & 1.58 & 0.50 & 1 & & & & & & & & & & \\
\hline 2. Age & 2.26 & 1.13 & $-.165^{*}$ & 1 & & & & & & & & & \\
\hline 3. Level of study & 1.27 & 0.44 & $-.260^{* *}$ & $0.418^{* * *}$ & 1 & & & & & & & & \\
\hline 4. Programme of study & 1.56 & 0.50 & $.419 * *$ & $-.301 * *$ & $-.423^{* *}$ & 1 & & & & & & & \\
\hline 5. Work experience & 2.07 & 1.32 & $-.139^{*}$ & $.795^{* *}$ & $.340^{* *}$ & $-.275^{* *}$ & 1 & & & & & & \\
\hline 6. Work location & 1.39 & 0.49 & .042 & $-.245^{* *}$ & $-.183 * *$ & $.273 * *$ & $-.231 * *$ & 1 & & & & & \\
\hline 7. Father's education & 4.02 & 2.32 & -.026 & .050 & -.004 & $-.134 *$ & .079 & .063 & 1 & & & & \\
\hline 8. Mother's education & 4.15 & 2.63 & $-.208^{* *}$ & $.229 * *$ & .062 & $-.158^{*}$ & $.186 * *$ & .076 & $.434 * *$ & 1 & & & \\
\hline 9.Access to media & 3.15 & 0.77 & -.018 & .087 & .083 & $-.131 *$ & .063 & $-.298 * *$ & -.083 & -.069 & 1 & & \\
\hline 10. Education on money & 2.50 & 1.19 & -.020 & .009 & -.121 & $.128^{*}$ & -.011 & .034 & .054 & -.022 & -.114 & 1 & \\
\hline 11. Financial Literacy & 44.64 & 14.19 & $-.262 * *$ & $.215^{* *}$ & -.021 & $-.401 * *$ & $.144 *$ & -.101 & -.033 & $.160^{*}$ & -.043 & -.038 & 1 \\
\hline
\end{tabular}

Notes: $N=250$; Correlation is significant at ${ }^{*} p<0.05 ;{ }^{* *} p<0.01$, all two-tailed tests

Table 2 reveals that a significant difference exists between financial literacy of male and female respondents, $[\mathrm{t}$ $(248)=4.27 ; \mathrm{p}<0.05]$. The finding shows that male working-students $(M=48.93, S D=14.54)$ demonstrate higher level of financial literacy than female working-students $(M=41.43, S D=13.09)$. Goldsmith and Goldsmith (1997) suggest that women score worse than men because in general women are less interested in the topics of investment and personal finance and, consequently, use financial services less often. Within the context of developing countries, different financial socialization during childhood is a major factor for this difference (Falahati \& Paim, 2011). Men are normally responsible for financial decisions in various households and are therefore more likely to understand financial concepts better than their female counterparts. Also, the findings revealed that a significant difference exists between financial literacy of business and non-business students, $\mathrm{t}$ $(247)=6.87 ; \mathrm{p}<0.05$. The findings indicate that business students $(M=51.15, S D=15.07)$ display higher financial literacy level than non-business students $(\mathrm{M}=39.79, S D=11.01)$. The finding, therefore, shows the effect of business students' prior knowledge in financially-related issues on their financial literacy scores. This finding supports previous studies (Chen \& Volpe, 1998, 2002) on financial literacy.

However, the results also showed no significant difference in financial literacy based on respondents level of study, $\mathrm{t}(247)=0.33 ; \mathrm{p}>0.05$, and location of workplace, $\mathrm{t}(248)=1.61 ; \mathrm{p}>0.05$. The lack of differences in level of study on financial literacy could be attributed to the absence of well-designed curricula on the subject. The basic concepts of economics and finance learnt at lower levels of participants' education are not improved upon at higher levels of education. Participants' level of study will therefore not contribute much to their literacy 
in finance. Table 2 further reveals that both respondents from urban $(M=45.78, S D=14.91)$ and rural areas $(M=42.84, S D=12.85)$ as well as undergraduate $(M=44.78, S D=13.79)$ and postgraduate students $(M=44.10$, $S D=15.37)$ on the average have equal knowledge in financial issues. Given the dearth of information and education on money matters in Ghana, the absence of differences in rural and urban respondents is not surprising. This result contradicts Cole, Sampson and Zia (2008), that people who live in rural area demonstrate the lowest level of financial knowledge.

Table 2. Summary of t-test analysis of differences in personal finance knowledge based on demographic characteristics

\begin{tabular}{lcccccc}
\hline & N & Mean & SD & df & $\underline{\mathbf{T}}$ & $\underline{\mathbf{p}}$ \\
\hline Gender & 107 & 48.93 & 14.54 & 248 & 4.27 & $0.000^{*}$ \\
Male & 143 & 41.43 & 13.09 & & & \\
Female & & & & & & \\
Level of study & 182 & 44.78 & 13.79 & 247 & 0.33 & $0.740 \dagger$ \\
$\begin{array}{l}\text { Undergraduate } \\
\text { Postgraduate }\end{array}$ & 67 & 44.10 & 15.37 & & & \\
$\begin{array}{l}\text { Programme type } \\
\text { Business }\end{array}$ & 109 & 51.15 & 15.07 & 247 & 6.87 & $0.000^{*}$ \\
Non-business & 140 & 39.79 & 11.01 & & & \\
$\begin{array}{l}\text { Location of workplace } \\
\text { Urban }\end{array}$ & 153 & 45.78 & 14.91 & 248 & 1.61 & $0.110 \dagger$ \\
Rural & 97 & 42.84 & 12.85 & & & \\
\hline$N=250 ;{ }^{*} p<0.05$ (Significant); $\dagger p>0.05$ (Not significant) & & & &
\end{tabular}

In order to determine whether there are mean differences of each demographic characteristic in respondents' financial literacy, one-way analysis of variance (ANOVA) with Tukey posit-hoc test was conducted as shown in Table 3. Financial literacy of student-workers were statistically different among demographic groups with different age, $F(4,225)=4.375, p=0.002$, and mother's education, $F(6,243)=3.487, p=0.003$. The post-hoc analysis revealed that working-students' with ages 20-27 years, 28-35 years and 36-43 years had significantly different mean financial literacy. Again, the post-hoc analysis showed that mother's with first degree and those with no schooling had significantly different mean in respondents' financial literacy. However, no significant difference in working-students' mean financial literacy was found among demographic groups of father's education, access to media and respondents' source of education on money.

Table 3. One-way ANOVA summary of demographic mean comparisons on Financial Literacy

\begin{tabular}{llccc}
\hline Variable & Sub-Characteristic & N & Mean & SD \\
\hline Age & 20-27 years & 68 & $40.15^{*}$ & 13.19 \\
& 28-35 years & 79 & $46.20^{*}$ & 14.06 \\
36-43 years & 48 & $49.58^{*}$ & 13.12 \\
& 44-51 years & 25 & 48.60 & 11.86 \\
52-59 years & 10 & 46.50 & 7.47 \\
& Total & $\mathbf{2 3 0}$ & $\mathbf{4 5 . 3 9}$ & $\mathbf{1 3 . 5 5}$ \\
& {$[F(4,225)=4.375, \mathrm{p}=0.002]$} & & & \\
& MSLC/BECE holders & 70 & 46.79 & 13.86 \\
& SSCE holders & 14 & 41.79 & 15.01 \\
& HND holder & 12 & 45.83 & 12.58 \\
& Cert A holders & 36 & 44.86 & 13.71 \\
& First degree & 37 & 39.19 & 12.05 \\
& Masters degree & 24 & 40.21 & 17.48 \\
& No school & 57 & 47.72 & 13.92 \\
& Total & $\mathbf{2 5 0}$ & $\mathbf{4 4 . 6 4}$ & $\mathbf{1 4 . 1 9}$ \\
& {$[F(6,243)=2.183, \mathrm{p}=0.045]$} & & & \\
& & & & \\
& & &
\end{tabular}


Table 3. One-way ANOVA summary of demographic mean comparisons on financial literacy (Continued)

\begin{tabular}{llccc}
\hline Variable & Sub-Characteristic & N & Mean & SD \\
\hline Mother's Education & MSLC/BECE holders & 80 & 43.56 & 12.36 \\
& SSCE holders & 20 & 40.75 & 17.27 \\
& HND holder & 8 & 43.75 & 15.29 \\
Cert A holders & 18 & 40.83 & 16.83 \\
& First degree & 20 & $36.75^{*}$ & 17.19 \\
& Masters degree & 6 & 39.17 & 17.15 \\
& No school & 98 & $49.03 *$ & 12.41 \\
& Total & $\mathbf{2 5 0}$ & $\mathbf{4 4 . 6 4}$ & $\mathbf{1 4 . 1 9}$ \\
& {$[F(6,243)=3.487, \mathrm{p}=0.003]$} & & & \\
Access to media & Very not accessible & 10 & 51.50 & 19.44 \\
& Not accessible & 27 & 42.04 & 8.80 \\
& Accessible & 128 & 45.40 & 814.23 \\
& Very accessible & 85 & 44.06 & 14.77 \\
Tource of Education on & Total & $\mathbf{2 5 0}$ & $\mathbf{4 4 . 6 4}$ & $\mathbf{1 4 . 1 9}$ \\
& Money issues & & & \\
& School/book 246$)=1.165, \mathrm{p}=0.324]$ & 83 & 46.51 & 14.20 \\
& Peers & 23 & 43.26 & 16.83 \\
& Parents & 81 & 41.67 & 14.36 \\
& Others & 63 & 46.51 & 12.46 \\
& Total & $\mathbf{2 5 0}$ & $\mathbf{4 4 . 6 4}$ & $\mathbf{1 4 . 1 9}$ \\
\hline
\end{tabular}

$N=250 ; *$ Significant difference occurred in means $(\mathrm{p}<0.05)$

\section{Limitations and Conclusion}

This study is not without limitations. In particular, the study was restricted to only one university in Ghana. Consequently, this could affect the generalizability of the findings. Again, capturing all scales with a single study questionnaire poses the problem of common method bias, which may have inflated the predictive relationships. Finally, the sample was skewed in that a significantly greater numbers of females and than males as well as non-business students than business students were captured. This possibly could be due to the sampling technique adopted by the study.

Despite these limitations, the current study successfully contributes to the extant literature on financial literacy by identifying the key variables that determine the level of financial knowledge among university students. We found that age and work experience are positive predictors of respondents' financial literacy. Also, mother's education was positively related with respondents' level of financial literacy. This confirms findings of previous work among college students (Lusardi et al., 2010). This implies that one of critical sources of information and education on financial issues for young adults is parents. However, level of study, work location, father's education, access to media and the source of education on money were all not significantly correlated with financial literacy. The finding showed that male working-students demonstrate higher level of financial literacy than female working-students. Within the developing country context, different financial socialization during childhood could be a major factor for this difference (Falahati \& Paim, 2011). Men are normally responsible for financial decisions in various households and are, therefore, more likely to understand financial concepts better than their female counterparts. Once again, we found that a significant difference exists between financial literacy of business and non-business students. The findings indicate that business students display higher financial literacy level than non-business students. The finding, therefore, shows the effect of business students' prior knowledge in financially-related issues on their financial literacy scores. This supports previous studies on financial literacy (Chen \& Volpe, 1998, 2002). However, the results also showed no significant difference in financial literacy based on respondents' level of study and location of workplace.

Given that there is a positive relationship between mother's (parent) education and financial literacy, we share in the recommendation that parents must be actively involved in designing such educational programs on financial issues at the basic and high school levels. According to Lusardi et al. (2010), parents who are engaged in such a program may take a more active role in guiding their children's financial behaviours. Second, such a program could aid those parents who lack sufficient financial knowledge to provide their children with sound financial advice. It is also significant for educational planners to note the variations in the level of financial literacy among 
participants. Male students performed better than female students while business major students did better than non-business major students. Thus, university students should not be considered as a homogeneous group with the same financial literacy limitations.

\section{References}

Agarwal, S., Driscoll J. C., Gabaix, X., \& Laibson, D. (2009). The age of reason: Financial decisions over the lifecycle. Brookings Papers on Economic Activity, 2, 51-117.

Ansong, A. (2011). Level of knowledge in personal finance by university freshmen business students, African Journal of Business Management, 5(22), 8933-8940. Retrieved January 12, 2012 from http://www.academicjournals.org/AJBM

Bajtesmit, V., \& Bernasek, A. (1996). Why do women invest differently than men? Financial Counselling and Planning, $\quad 7, \quad 1-10 . \quad$ Retrieved January $15, \quad 2012$ from http://www.biz.colostate.edu/faculty/vickieb/cv_bajtelsmit_Aug04_withpres.DOC

Bernheim, D. (1998). Financial Illiteracy, Education and Retirement Saving. In O. S. Mitchell, \& S. Schieber (Eds.). Living with defined contribution pensions, (pp.38-68). Philadelphia: University of Pennsylvania Press.

Bluman, A. G. (2001). Elementary statistics: A step by step approach. Boston: McGraw-Hill Higher Education.

Chen, H., \& Volpe, R. P. (1998). An analysis of personal financial literacy among college students. Financial services review, 7(2), 107-128. http://dx.doi.org/10.1016/S1057-0810(99)80006-7 (December 23, 2011).

Chen, H., \& Volpe. R. P. (2002). Gender differences in personal financial literacy among college students. Financial Services Review, 11(3), 289-307. Retrieved February, 11, 2012 from www2.stetson.edu/fsr/abstracts2/Vol11_A18.pdf

Cole, S., Sampson, T., \& Zia, B. (2008). Money or knowledge? What drives the demand for financial services in developing countries? Harvard Business School Working Paper, 9, 117. Retrieved February 12, 2012 from www.hbs.edu/research/pdf/09-117.pdf

Dahlia, I., Rabitah, H., \& Zuraidah, M. I. (2009). A study on financial literacy of Malaysian degree students. Cross-Cultural Communication, 5(4), 51-59. Retrieved January 15, 2011 from cscanada.net/index.php/ccc/article/download/773/772

Falahati, L., \& Paim, L. (2011). Gender differences in financial well-being among college students. Australian Journal of Basic and Applied Sciences, 5(9), 1765-1776. Retrieved January 21, 2012 from http://www.insipub.com/ajbas/2011/September-2011/1765-1776.pdf

Goldsmith, E. B., \& Goldsmith, R. E. (1997). Sex differences in financial knowledge: A Replication and Extension. Psychological Report, 81, 1169-1170. Retrieved January 15, 2011 from www.ipfp.k-state.edu/documents/jpf/05/02/investedu.pdf

Guiso, L., \& Jappelli, T. (2003). Financial literacy and portfolio diversification. CSEF Working Paper, No.212. Retrieved January 15, 2011 from www.csef.it/WP/wp212.pdf

Illeris, K. (2004). Three dimensions of learning. Malabar, FL: Krieger Publishing.

Lim, V. K. G., Teo, T. S. H., \& Loo, G. (2003). Sex, financial hardship and locus of control: an empirical study of attitudes towards money among Singaporean Chinese. Personality and Individual Differences, 34, 411-429.

Lusardi, A., \& Mitchell, O. S. (2007b). Financial literacy and retirement planning: New evidence from the Rand American Life Panel. Working Paper 2007-157, University of Michigan Retirement Research Center. Retrieved January 11, 2011 from www.mrrc.isr.umich.edu

Lusardi, A., Mitchell, O.S., \& Curto, V. (2010). Financial literacy among the young. Journal of Consumer Affairs, 44(2), 358-380. Retrieved January 11, 2011 from www.mrrc.isr.umich.edu

Lusardi, A., \& Tufano, P. (2009). Debt literacy, financial experience and over indebtedness. NBER Working Paper No. W14808, National Bureau of Economic Research. Retrieved from www.mrrc.isr.umich.edu

Mandell, L. (2008). Financial education in high school. In A. Lusardi (Ed.). Overcoming the saving slump: How to increase the effectiveness of financial education and saving programs, (pp.257-279). Chicago: University of Chicago Press.

Nellie, M. (2002). Undergraduate students and credit cards: An analysis of usage and trends. 
Norvilitis, J. M., Merwin, M. M., Osberg, T. M., Roehling, P. V., Young, P., \& Kamas, M. M. (2006). Personality factors, money attitudes, financial knowledge, and credit-card debt in college students. Journal of Applied Social Psychology, 36(6), 1395-1413.

Norvilitis J. M., \& Santa, M. P. (2002). Credit card debt on college campuses: Causes, consequences, and solutions. College Student Journal, 36, 356-363.

Norvilitis, J. M., Szablicki, P. B., \& Wilson, S. D. (2003). Factors influencing levels of credit card debt in college students. Journal of Applied of Social Psychology, 33, 935-947.

Norman, A. S. (2010). Importance of financial education in making informed decision on spending. Journal of Economics and International Finance, 2(10), 199-207.

Olga, K. (2011). Financial literacy in Ukraine: Determinants and implications for saving behaviour. Unpublished master's thesis, Kyiv School of Economics.

Ormrod, J. E. (1995). Human learning. Englewood Cliffs, NJ: Prentice Hall.

Peress, J. (2004). Wealth, information acquisition, and portfolio choice. The Review of Financial Studies, 17, 879-914. Retrieved January 11, 2011 from faculty.insead.edu/peress/personal/erratum_rfs2004.pdf

Powell, M., \& Ansic, D. (1997). Gender differences in risk behaviour in financial decision-making: An experimental analysis. Journal of Economic Psychology, 18(6), 605-628. Retrieved January 11, 2011 from ftp.iza.org/dp3985.pdf

Roberts, J. A, \& Jones, E. (2001). Money attitudes, credit card use, and compulsive buying among American college students, Journal of Consumer Affairs, 35, 213-240.

Schubert, R., Brown, M., Gysler, M., \& Brachinger, H. W. (1999). Gender and economic transactions-Financial decision-making: Are women really more risk-adverse? The American Economic Review, 89(2), 381. Retrieved January 11, 2011 from www.econ.ethz.ch/people/.../publ_schubert.pdf

van Rooij, M., Lusardi, A., \& Alessie, R. (2007). Financial literacy and stock market participation. NBER Working Paper No. W13565, National Bureau of Economic Research. Retrieved January 11, 2012 from www.nber.org/papers/w13565.pdf

van Rooij, M., Lusardi, A., \& Alessie, R. (2008). Financial literacy, retirement planning, and household wealth. Paper presented at the ECB-CFS Conference on Household Finances and Consumption, Frankfurt am Main, Germany, September 4-5, 2008. Retrieved January 11, 2012 from www.dnb.nl/.../PhDThesis\%20Maarten\%20van\%20Rooij_tcm47-211...

Wilhelm, M. S., Varcoe, K., \& Fridrich, A. H. (1993). Financial Satisfaction and Assessment of Financial Progress: Importance of Money Attitudes. Journal of Financial Counselling and Planning, 4, 181-199. 